Boise State University ScholarWorks

World Languages Faculty Publications and

Presentations

Department of World Languages

$1-1-2018$

\title{
Looking for a Needle in a Haystack: CALL and Advanced Language Proficiency
}

Jack Burston

Kelly Arispe

Boise State University 
This is an author-produced, peer-reviewed version of this article. The final, definitive version of this document can be found online at Calico

Journal, published by the Calico Journal. Copyright restrictions may apply. doi: 10.1558/cj.31594

\title{
Looking for a Needle in a Haystack: CALL and Advanced Language Proficiency
}

\author{
Jack Burston \\ and \\ Kelly Arispe \\ Boise State University
}

\begin{abstract}
The goal of this meta-analysis is to evaluate how instructional technology has impacted advanced second language (AL2) development. Although numerous meta-analyses have been conducted within the CALL literature over the past two decades, they primarily focus upon learning outcomes and related effect sizes. None focus on advanced learning per se. Where AL2 is even mentioned, which is only rarely, little or no attention is paid to critical research parameters within the studies that are analyzed. Most notably, in summarizing learning outcomes, the linguistic competence of learners claimed to be at advanced level is simply taken at face value. So, too, no consideration is given to the difficulty level of tasks undertaken by students or their appropriateness to students' claimed proficiency. It is the intent of this general overview of the contribution of CALL to AL2 to address these issues through a comprehensive analysis of the publications in four prominent CALL journals (CALICO, CALL, Language Learning \& Technology, and ReCALL) over some 30 years. In so doing, the Performance Descriptors (PD) and NCSSFL- Can-Do Statements (CDS) of the American Council on the Teaching of Foreign Languages' (ACTFL) are adopted as external criteria for establishing student competence level, task difficulty and appropriateness. This study concludes that not only are CALL AL2 studies extremely limited in number and focus, but also that they suffer from serious design flaws that call into question a great portion of the claims made regarding the contribution of instructional technology to the furthering of advanced-level foreign language competence.
\end{abstract}

Keywords: advanced, meta-analysis, proficiency, ACTFL, instructional technology

\section{Introduction}

This meta-analysis evaluates the contribution of Computer-Assisted Language Learning (CALL) to advanced-level foreign language instruction (AL2) from 1983 to 2015 as reflected in the pages of four prominent CALL journals: CALICO, CALL, Language Learning \& Technology ( $L L \& T)$, and ReCALL. Firstly, it summarizes descriptive data for CALL AL2 implementation studies in these four journals. Secondly, it evaluates the experimental and pedagogical design within those studies to determine if CALL was effective in moving learners along the continuum to advanced language proficiency. To date, no meta-analysis within CALL has looked at these two parameters.

In considering the contribution of instructional technology to AL2 teaching, one is immediately struck by how little of the published CALL research concerns itself with advanced language learners. In fact, fewer than $3 \%$ of the articles in the above journals fall into this category. The paucity of work in this area stems from three contributing factors: technological, pedagogical, and institutional. Although computer technology has been applied to language instruction for over 50 years, it has only been within the past decade that multimedia communication affordances have been available to support language learning beyond beginning and intermediate levels. Given what the technology was able to accommodate, until recently most pedagogical applications were restricted to behaviorist, structuralist, drilling of grammar and vocabulary acquisition. However, to this day, even with the exploitation of the most modern technologies, true-false, multiple-choice, and gap-fill grammar and vocabulary exercises remain widespread. Quite independently of technological constraints, foreign language instructional technology has lagged, and continues to 
This is an author-produced, peer-reviewed version of this article. The final, definitive version of this document can be found online at Calico Journal, published by the Calico Journal. Copyright restrictions may apply. doi: 10.1558/cj.31594

lag, behind the kind of learner-centered, communicative, pedagogical practices that lend themselves to more advancedlevel competence. Above all, the lack of AL2 research in CALL is a reflection of the dearth of foreign language instruction at this level. This is particularly so in the United States.

In the US, according to the ACTFL K-12 Foreign-Language Report (2010), only 18.5\% of K-12 students were learning a foreign language. At the post-secondary level, in 2013 less than half that percentage was enrolled in foreign language courses (Goldberg, Looney \& Lusin, 2015). Moreover, foreign language study in America takes place almost entirely below the intermediate level (Adelman, 1995). While this would be expected in primary and secondary schools, the same holds true in colleges and universities. Where they exist, which is only in about half of post-secondary institutions (Lusin 2012), foreign language BA/BS degree requirements are usually met with first-year beginners' courses. Only in institutions that require two years of study, which account for less than a quarter of those with a foreign language requirement (Lusin 2012), do successful learners begin to reach an intermediate level of language competence. In 2013, of the total undergraduate foreign language enrollments, less than $1 \%$ were fourth-year majors (Goldberg, Looney \& Lusin, 2015). However even among graduating foreign language majors, judging by the results of published assessments of their L2 competence, advanced-level instruction cannot be taken for granted. In the nearly fifty years since Carroll (1967) undertook an extensive survey of graduating foreign language majors, the language competence level of a large proportion of graduating foreign language majors remains at Intermediate-high. According to the most recent evaluation of the competence level of graduate teacher certification candidates (Glisan, Swender \& Surface, 2013) nearly half (46\%) failed to score above Intermediate-high on the ACTFL scale ("ACTFL Performance Descriptors for Language Learners”, 2015).

These worrisome statistics were the catalyst in exploring the role that CALL has played in furthering AL2 proficiency. If just $54 \%$ of graduating teacher candidates, who presumably are among the most motivated language students, are reaching advanced levels even in commonly taught languages like English, Spanish, and French, it warrants investigating how technology has affected learning outcomes at the advanced level. Thus, the present meta-analysis investigates the extent to which, if any, CALL has contributed to improved AL2 proficiency as defined by ACTFL.

\section{The Question of Proficiency}

At first glance, there are two striking features when looking at the CALL research depicted in the four journals analyzed in this meta-analysis: 1) a paucity of AL2 language contexts in general and 2) a focus on the written language. It may be the case that AL2 learners are ignored because, at least in the U.S., they are few in number; but it may also be the case that, compared to beginning and intermediate level learners, they are difficult to pinpoint due to greater ranges in proficiency and more variability in linguistic backgrounds as learners advance. A typical AL2 Spanish class in the U.S. welcomes native speakers, heritage language learners and second language learners alike-all with different language backgrounds and experiences (study abroad, internships, etc.). Which is not to say that AL2 learners, whatever their background or learner profile, can't meet tangible benchmarks on the path towards improved language proficiency. The heterogeneous nature of AL2 learners and learner contexts provides a unique opportunity for CALL researchers and practitioners to explore how instructional technology can mitigate these challenges in variability toward improved language competence.

The objective of this analysis is to determine which of the publications reviewed in this study lead to proficiency gains using criteria based on ACTFL guidelinesi. ACTFL defines proficiency as "the ability to use language in real world situations in spontaneous interaction and non-rehearsed context and in a manner acceptable and appropriate to native speakers of the language” (“ACTFL Performance Descriptors”, 2015, p.4). Conceptually, proficiency-based definitions of language learning help learners and educators make sense of language learning and set goals that propel learners forward. ATCFL also provides Performance Descriptors (PD) and NCSSFL- Can-Do Statements (CDS) which, in tandem with the Proficiency Guidelines, can lead to conscientiousness about realistic expectations for improving language proficiency over time. Additionally, ACTFL provides assessments that determine learners' proficiency level for each of the four skills. These assessments are often used by employers to corroborate linguistic skills of employees. Furthermore, institutions (K-12 and Higher Education) use ACTFL proficiency- based standards for accreditation and program-assessments. There is good motivation, therefore, to demonstrate how CALL affects language proficiency according to ACTFL's criteria. 
This is an author-produced, peer-reviewed version of this article. The final, definitive version of this document can be found online at Calico Journal, published by the Calico Journal. Copyright restrictions may apply. doi: 10.1558/cj.31594

\section{Research Questions}

\section{$\underline{\text { 3.1 Previous CALL Meta-Analyses }}$}

Cumulative CALL analyses are not new nor are they lacking; in fact nearly 30 have been published in the past dozen years. They have been organized around central themes in CALL: CALL effectiveness (Felix, 2005; Felix, 2008), Computer Mediated Communication (Lin, 2014; Nguyen, 2008), Gaming (Chiu, et al., 2012), Glossing (Taylor, 2013; Yun, 2011), Mobile Assisted Language Learning (Burston, 2015) and Synchronous Computer Mediated Communication (Ziegler, 2015), to name a few. Most recently, Plonsky and Ziegler (2016) conducted a second-order synthesis (i.e., a meta-analysis of meta-analyses), to determine the overall effectiveness of CALL projects in general as well as to look specifically at methodological rigor in ten meta-analyses. Among these, Lin (2014) in particular looks at effect size, taking into consideration a myriad of variables including learners' L2 proficiency level. It is to be noted that Lin corroborates the findings of the present analysis in regard to the very low presence of AL2 studies. So, too, Lin points to a pervasive experimental design flaw in that a majority of studies simply make assumptions about the level of the participants in their study with no supporting evidence, thereby raising concern about any conclusions drawn regarding the effect of CALL on learning outcomes:

'Furthermore, to investigate if learners' target language proficiency has an impact on the effect of CMC, effect sizes were calculated for three levels of proficiency: elementary, intermediate and advanced. The results show that elementary-level students benefit more from CMC than both intermediate - and advanced-level students. The level of proficiency was determined by the primary researchers, who employed various types of measurements or who simply made such judgments based on their understanding of the students, and thus this variable is by no means to be taken as valid.” (p.134).

Despite the impressive number of parameters included in Lin's study, one critical variable is missing: the proficiency level required by the task in question. This isn't addressed either in any of the other studies reviewed by Plonsky and Ziegler (2016). In sum, CALL meta-analyses to date come to fundamental conclusions about the relationship between CALL and SLA which to a large extent are predicated on assumptions and vague details about learner proficiency levels and the linguistic competency required to complete project tasks.

\subsection{Research Questions}

To date, there has been no meta-analysis that centers on the AL2 proficiency in CALL. Using Lin (2014) as a point of departure, the present study focuses on descriptive and analytic inquiries relating to the five fundamental research questions below:

1. How are CALL AL2 studies characterized?

2. What is the claimed proficiency level of the participants and how is this substantiated?

3. What is the proficiency level required by assigned tasks and how is it substantiated?

4. Do CALL materials in question improve AL2 learners' linguistic proficiency?

5. What is the relationship between linguistic task difficulty and the proficiency level of the participants?

\section{Methodology}

\section{$\underline{\text { 4.1 Selection Criteria }}$}

Identification of the papers involving AL2 in the four journals examined here was considerably less straightforward than might be expected. One reason for this is that online archives differ in the search flexibility they offer. CALICO and CALL support keyword searches of full texts independently of volume and issue, i.e., they find search strings anywhere in the entire archive. $L L \& T$ and $\operatorname{Re} C A L L$, on the other hand, only allow individual title indexes to be searched by volume and issue. A second reason for the difficulty in locating research data on AL2 is that, surprisingly, the keyword "advanced" does not frequently occur in the title of articles involving AL2. Of the articles initially identified in this study, on average, only $25 \%$ of the titles contained the word "advanced". Consequently, for the 
This is an author-produced, peer-reviewed version of this article. The final, definitive version of this document can be found online at Calico Journal, published by the Calico Journal. Copyright restrictions may apply. doi: 10.1558/cj.31594

journals that restricted direct searches to title information, the only effective way to locate articles involving AL2 was to read through all the titles, volume by volume, looking for language learning specializations that suggested advanced levels, for example "LSP, Languages for Specific Purposes”, “ESP, English for Specific Purposes”, "ESAP, English for Specific Academic Purposes”, “academic writing”, etc. Once a suggestive title was located, the abstract was then consulted in search of evidence of reference to AL2. When this proved fruitful, the full article was then manually searched for the keywords "advanced", "level”, "student", "participant". The keyword "methodology" was also searched because, following standard practice in applied linguistics studies, there is typically a section with this name that gives information about participants including their language proficiency level.

Based on the above key word searches, 68 AL2 papers were found in the four journals, out of the some 1840 publications, i.e., only 3.4\% of the total. However, this in fact over- estimates the number of studies involving AL2, since what is considered to constitute advanced- level instruction is anything but consistent. In a number of cases, authors offer no definition at all other than a generic allusion to the advanced level of the students. When definitions are provided, they are based on four types of criteria: years of previous study, current course enrollment, standardized test results, and prima facie evidence. Needless to say, the number of years of previous study provides a very unreliable means of assessing language competence.

Were it otherwise, there would be no need for external standardized tests. Likewise, without corroborative substantiation, the mere enrollment in a course labeled Advanced X provides no reliable measure of advanced language level. For this reason, only CALL studies involving advanced-level competency defined relative to objective external assessments and/or convincing prima facie evidence were retained for this meta-analysis. External tests included the TOEFL, IELTS, TEPS (South Korea), and Michigan language examinations. Prima facie evidence included a variety of factors. Based on the findings of Glisan, Swender \& Surface (2013), it is reasonable to assume that the majority (albeit slim) of fourth-year language students in the US would be at or above the advanced-low level. In any event, students in fourth-year language department courses are as advanced as one will find among undergraduates in US colleges and universities. For these reasons, CALL studies involving fourth-year language students in the US have been included. Studies involving full-time ESL students regularly enrolled as undergraduates or graduates in tertiary institutions where English is the language of instruction were likewise included. Also accepted for inclusion were studies involving third/fourth-year language specialists in institutions where students take only courses related to their L2. So, too, given the higher attested foreign language competence of their students ("European Commission”, 2012), European university studies at any level were also retained. Owing to the AL2 competence normally required, courses described as advanced-level English for Academic or Specific Purposes were included as well. Where students in a study had spent considerable time living in a country where the L2 was spoken, this was also taken as corroborating evidence of AL2 competency.

In accordance with the above selection criteria, a total of 53 of the initial 68 AL2 papers remained for analysis. However, six of the latter were eliminated from consideration because they did not involve pedagogical implementations. Two of these were design descriptions, three software reviews and one a report that focused on instructional technology usage. The remaining 47 pedagogical studies form the basis of this study. The majority of these, 18, were found in CALICO, with $L L \& T$ and ReCALL contributing 14 and 10, respectively. Only 5 papers from $C A L L$ were included. In terms of the relative proportion of the 47 retained AL2 papers to total publications, $L L \& T$ at $5.3 \%$ (14/264) ranked highest followed by CALICO with $3 \%$ (18/600) and ReCALL at 2.7\% (10/370). CALL ranked last with less than $1 \%$ (5/606) of its research publications related to AL2. On average then, when controlled for reliable definitions of advancedness, between 1983 and 2015 only 2.6\% of the total publications in the journals under review have dealt with AL2 pedagogical implementations.

\subsection{Coding}

In all, the 47 studies were coded three times. First, descriptive, face-value information about the studies was summarized in a spreadsheet. Since this information did not require analysis or the use of any external criteria, the researchers worked together to input this data as it related to research question one. For the second and third rounds of coding, the researchers used external criteria based on ACTFL standards, namely the Performance Descriptors (PD) and Can-Do statements (CDS), to independently keep track of parameters relating to research questions two (student competence level), three (level of the task) and four (did the participants improve?). These descriptors "help educators set realistic expectations at the summative assessment level. The ability to look ahead to the next range of performance allows instructors to create assessments that show what the language learner is able to do within the learner's current 
This is an author-produced, peer-reviewed version of this article. The final, definitive version of this document can be found online at Calico Journal, published by the Calico Journal. Copyright restrictions may apply. doi: 10.1558/cj.31594

range as well as how well the learner is able to perform in the next higher range" ("ACTFL Performance Descriptors for Language Learners", 2015, p.3). Once the level of the participants and the level of the task were determined, the researchers coded for task appropriateness by measuring the difference between the two (i.e. task difficulty-participant level). It was decided that for any given level of competence, a task that met that level or went just one sub-level beyond was deemed "appropriate", adhering to the notion of $\mathrm{i}+1$ scaffolding and the natural progression of proficiency as modeled by the ACTFL documents.

The PD document was used in the following manner:

1. Determine the mode of communication in which students engaged: interpretive, interpersonal or presentational

2. Analyze the seven domain descriptions for the mode at the advanced level

3. Code for similarities or matches between key words in the domain descriptions (at the advanced level according to the mode of communication) and the task, learning objective and/or results in the study (i.e., what was measured)

Similarly, the CDS were used to corroborate that the objective of the task was either at the proficiency level (e.g., Advanced-low) or just one sub-level beyond (e.g., Advanced-mid) the inferred/given competence level of the participant. This process was similar to that used for the PD:

1. Determine the mode of communication: interpretive (listening or reading), interpersonal or presentational (writing or speaking)

2. Analyze the global benchmark description for the mode in the study at the advanced level ranges (i.e., Advanced-low, Advanced-mid, Advanced-high and Superior)

3. Code for the proficiency level where the task in the study aligns to one of the CDS according to mode (exact wording was not required but the task(s) in the study and the CDS needed to be similar).

When the PD and CDS documents were consulted for coding in rounds two and three, the researchers did so independently using a Google form. At intervals of 15, the researchers reviewed their responses and highlighted cells where responses did not match. Both researchers then analyzed the study again and communicated their rationale at their next meeting online in order to reach a consensus.

\section{Results}

Research Question 1: How are CALL AL2 studies characterized?

\subsection{Descriptive Data}

Although the earliest CALL publications date from the appearance of the CALICO Journal in 1983, in the 32 years since then only one of the 47 studies relating to AL2 was published prior to 2000 (Figure 1). Afterwards, with the exception of 2010, no more than 5 AL2 papers per year appear in the combined pages of the four journals under review. 
This is an author-produced, peer-reviewed version of this article. The final, definitive version of this document can be found online at Calico Journal, published by the Calico Journal. Copyright restrictions may apply. doi: 10.1558/cj.31594

\section{AL2 Studies Publication Year}

$$
9
$$

8

7

6

5

4

3

2

1

0

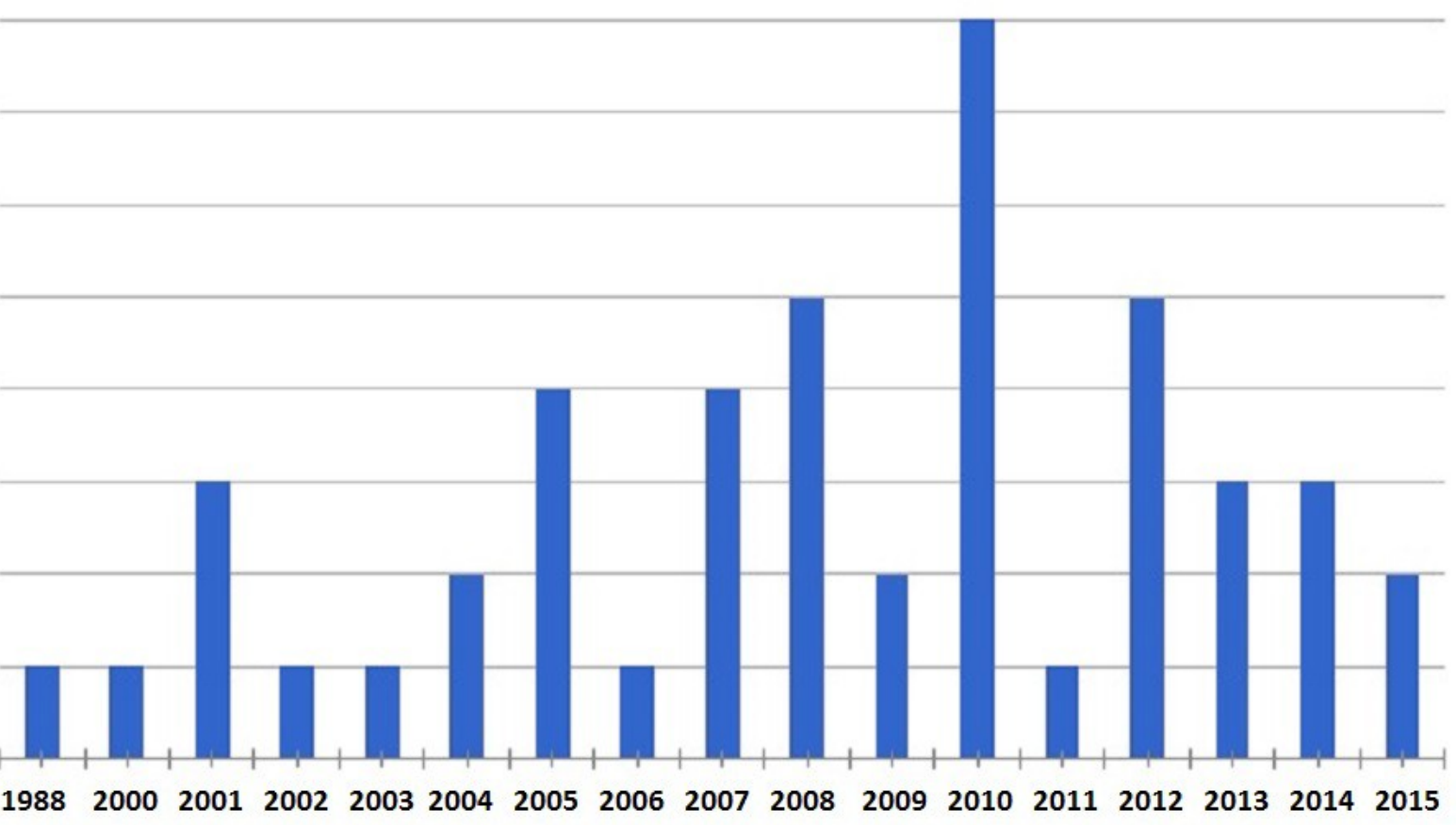

Figure 1

By far, at nearly 37\%, the greatest numbers of studies were undertaken in the US, followed by the UK and Taiwan at just under 10\% each (Figure 2). The remainder of publications came from a total of fourteen other countries. 
This is an author-produced, peer-reviewed version of this article. The final, definitive version of this document can be found online at Calico Journal, published by the Calico Journal. Copyright restrictions may apply. doi: 10.1558/cj.31594

Source Countries of AL2 Studies

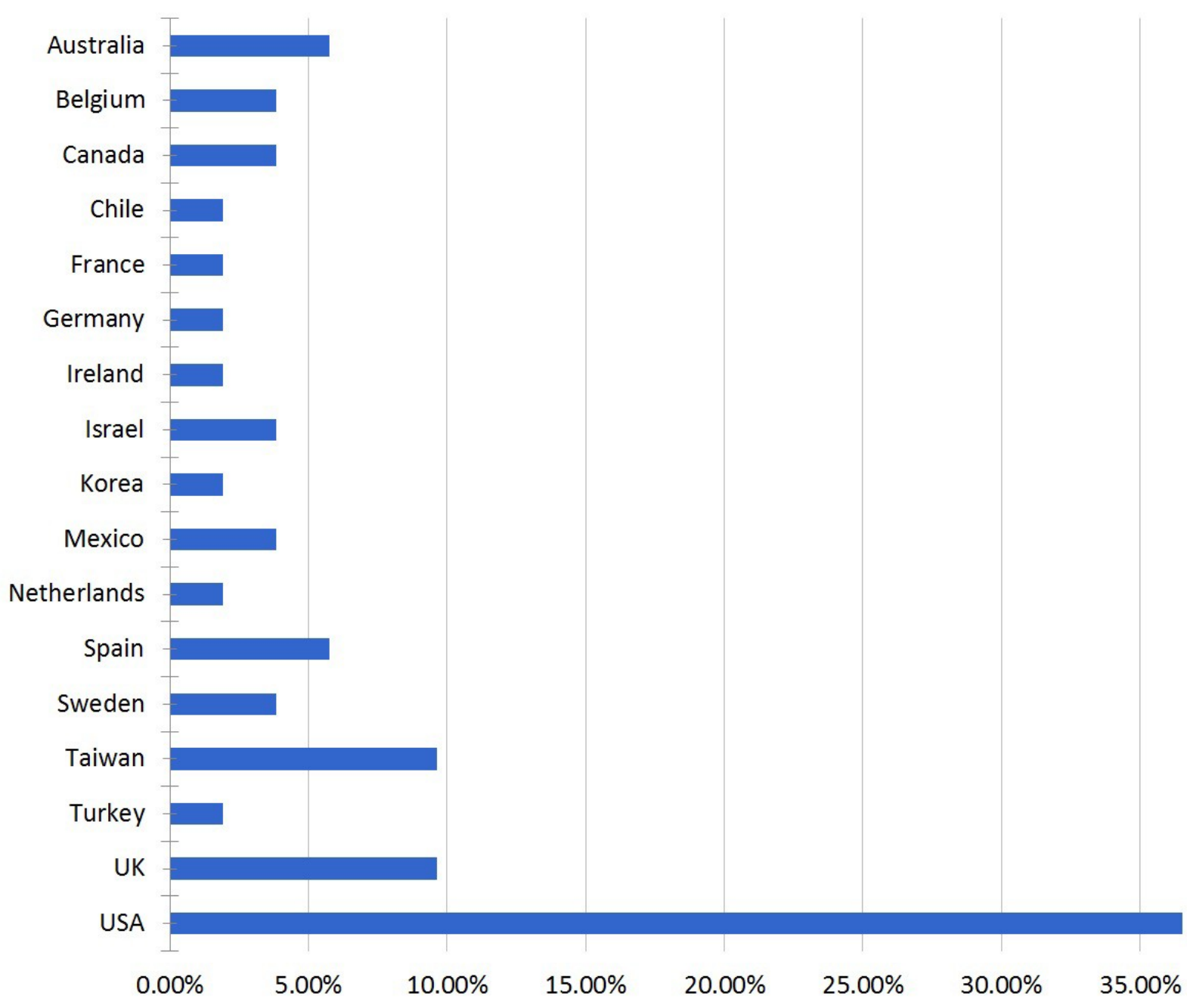

Figure 2

Identification of the L1 of students is lacking in nearly $19 \%$ of the studies (Figure 3). Where it is specified, Chinese ranks first with $24 \%$ followed by English, Korean and Spanish at 17\%, 13\% and 10\%, respectively. Fourteen other languages constitute the remaining $\mathrm{L} 1$. 
This is an author-produced, peer-reviewed version of this article. The final, definitive version of this document can be found online at Calico Journal, published by the Calico Journal. Copyright restrictions may apply. doi: 10.1558/cj.31594

\section{L1 of Students}

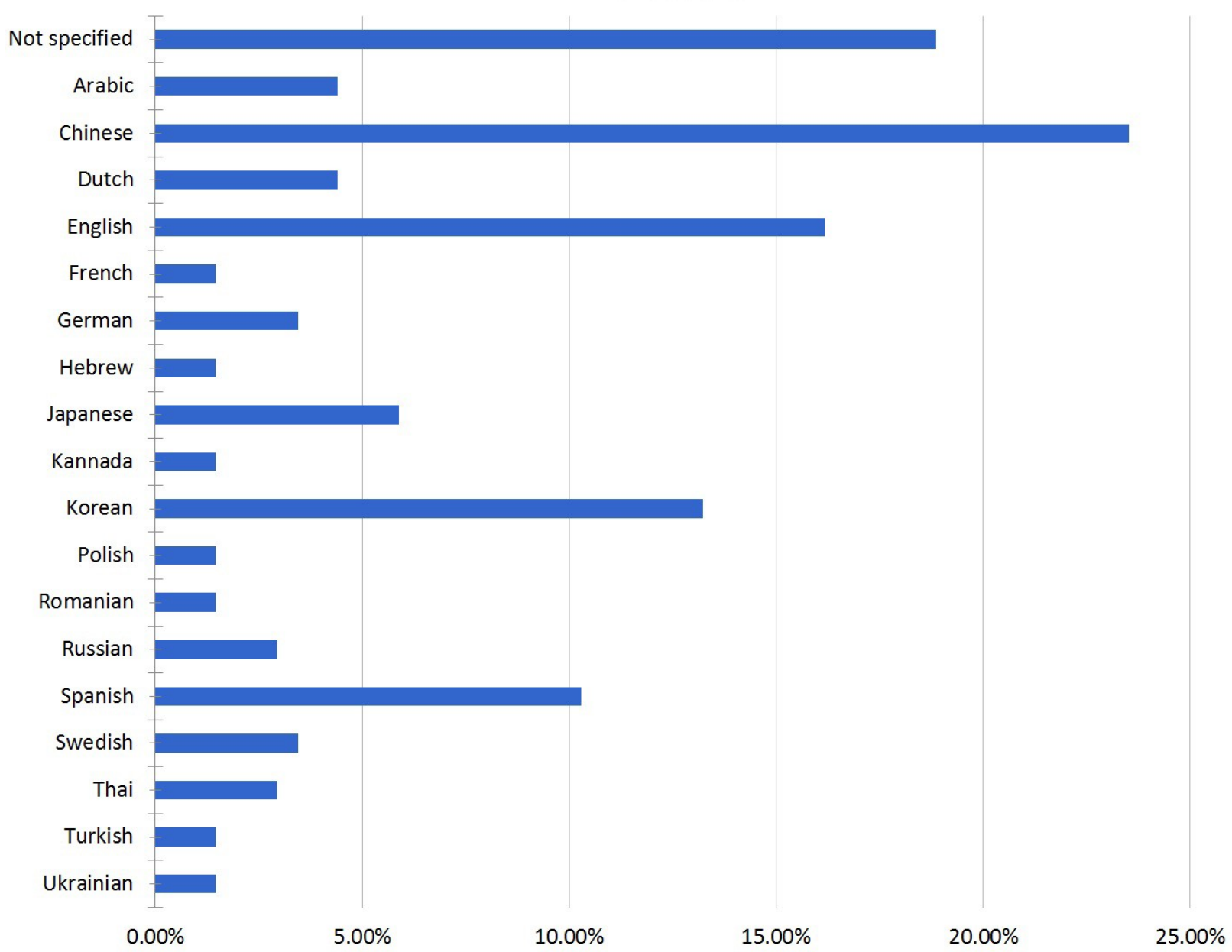

Figure 3

As can be seen in Figure 4, nearly 62\% of AL2 studies has targeted ESL/EFL. This is followed in a distant second and third place by German (13.5\%) and French (11.5\%). Four other languages complete the inventory: Spanish (5.6\%), Chinese (3.8\%), and Arabic and Russian at less than $2 \%$ each. So, too, some $79 \%$ of the studies involved research experiments with course implementations trailing far behind at only $21 \%$. 


\section{Advanced-level Languages}

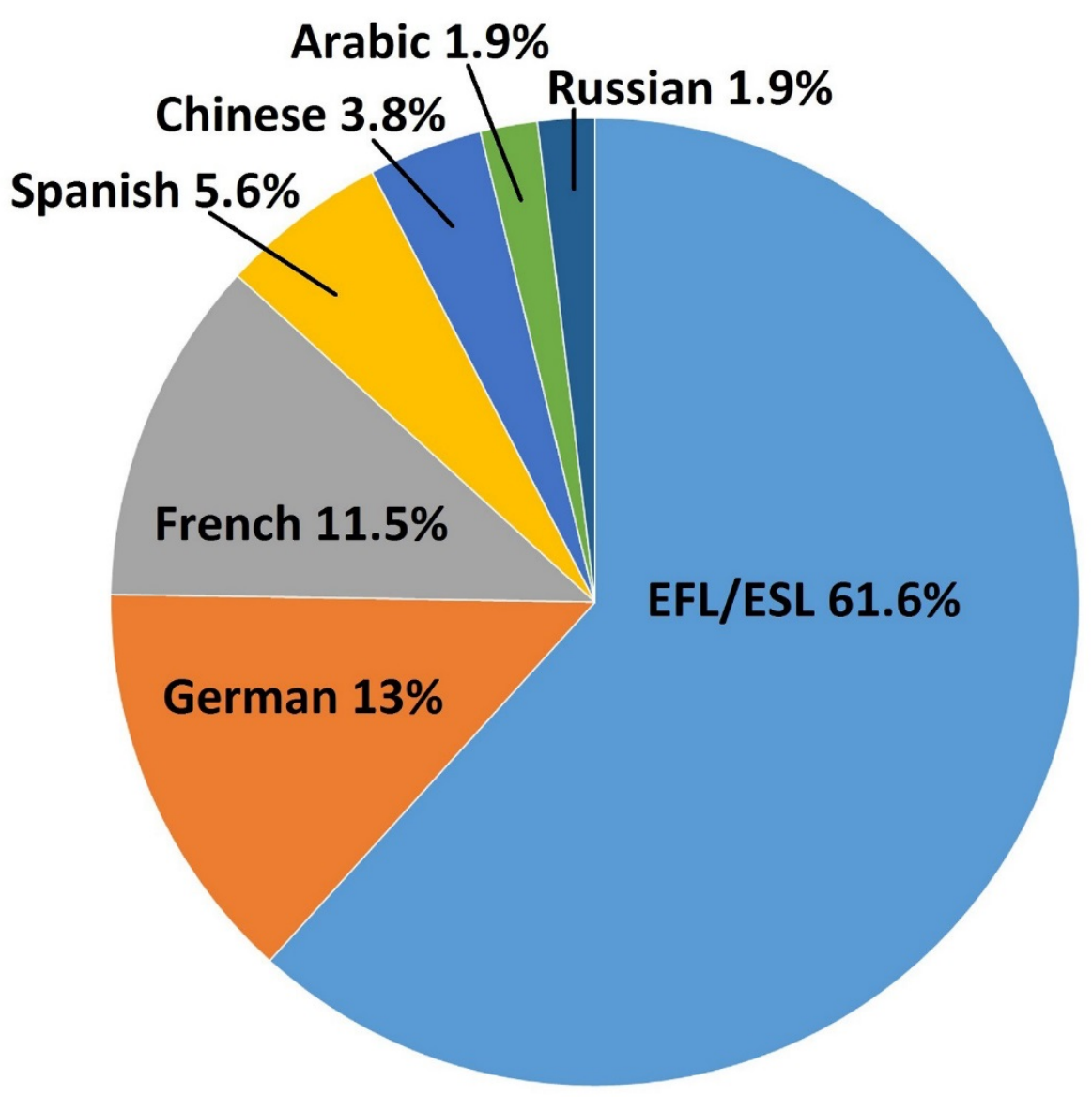

Figure 4

Lastly, in all, nearly $81 \%$ of AL2 studies focused on the written language (Figure 5), of which presentational and interpersonal writing accounted for $63 \%$ and interpretive reading $18 \%$. In contrast, presentational and interpersonal speaking and interpretive listening together were targeted in only $16 \%$ of the studies. 
This is an author-produced, peer-reviewed version of this article. The final, definitive version of this document can be found online at Calico Journal, published by the Calico Journal. Copyright restrictions may apply. doi: 10.1558/cj.31594

\section{Pedagogical Focus}

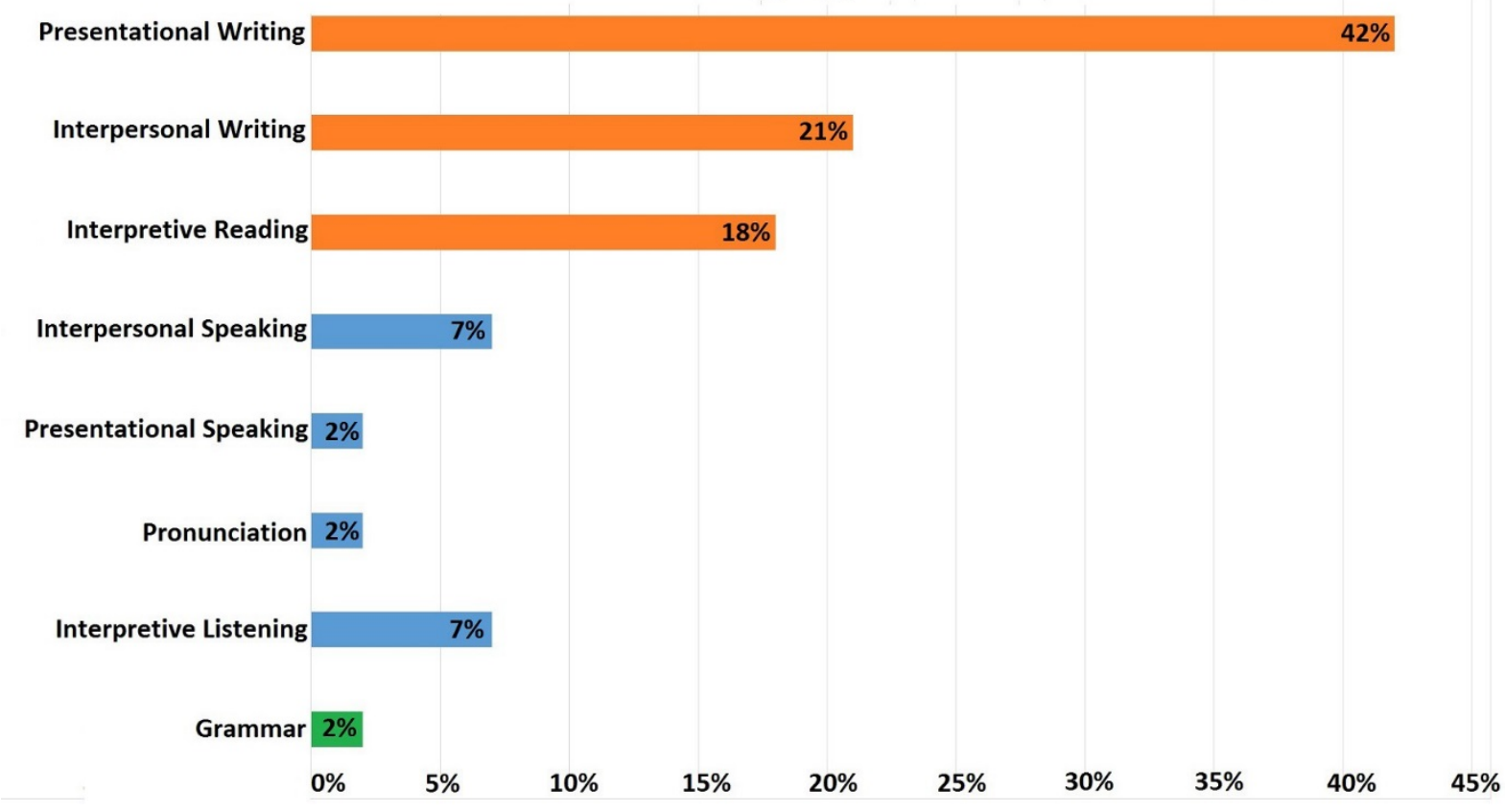

Figure 5

\section{$\underline{1.2}$ Linguistic Data}

\section{Written Language}

Beginning with the predominant written language paradigm, a closer inspection of the 24 AL2 studies that focus specifically on presentational writing skills reveals that 13 involve collaborative composition activities and 11 individual writing exercises. Seven collaborative projects [14,27,29,30,36,39,40] involve shared input using discussion forums, wikis, blogs, chats and Google docs. Six [3,13,19,22,24,43] engage students in peer-based critical feedback using email, blogs, and wikis. Corpus-based studies account for six of the individual writing activities. These involved concordancing activities [6] and the modeling of academic texts [7,9,23,32,47]. A concern with metacognitive self-regulation guided the remaining studies, two of which involve grammatical accuracy [4,5], one reflective scaffolding [11] one translation commentary [37] and one technology acceptance [41].

A number of the studies that specifically target presentational writing [24,29,30,36,40] also involve other activities, most notably written interpersonal communication. However, the majority of written interpersonal communication studies [1,2,10,17,25,26,35,38,42,44] focus on text-based CMC (i.e., chats, discussion forums, blogs) which target interaction that does not result in any formal written production. Three of the studies involving presentational writing [24,30,36] also engage students in spoken interpersonal exchanges. The most extensive of these [30] was a business scenario role play that also required presentational speaking, online reading and listening. One other interpersonal communication study [31] also focuses on speaking skills in conjunction with listening comprehension.

The emphasis on the written language is further extended in ten studies that target reading comprehension of online texts. Besides the previously mentioned presentational writing studies [30,37], four tested the effectiveness of hypermedia texts [12,15,16,18], one trialed an interactive dictionary [20], one worked with concordances [34], another on scanning and skimming skills [28], and one analyzed student reading comprehension strategies [33]. 
This is an author-produced, peer-reviewed version of this article. The final, definitive version of this document can be found online at Calico Journal, published by the Calico Journal. Copyright restrictions may apply. doi: 10.1558/cj.31594

\section{Other Language Areas}

In all, only 10 studies devote any attention to aural/oral skills. Besides the five already indicated that involve presentational [30] and interpersonal speaking [24,30,31,36], one targeted pronunciation correction [21] and four listening comprehension [8,30,31,45]. Lastly, one study was grammar-based [46].

Research Question 2: What is the claimed proficiency level of the participants and how is this substantiated?

As mentioned at the outset, the AL2 CALL publications in this study are frustratingly imprecise in identifying the language competency level of students, to the point where 15 (22\%) of the original 68 had to be eliminated from consideration because of their vagueness in this regard. The majority of the studies required interpretation with regard to the proficiency levels of the participants in question. Of the 47 papers involving pedagogical implementations retained in the present study, only nine (19\%) [15,16,17,21,27,33,37,46,47] explicitly substantiate student L2 competency by reference to objective external test results (e.g., TOEFL scores). Another 12 (25\%) $[2,7,8,10,11,12,24,28,31,34,35,39]$ specifically identify the competence level of their students (e.g., Advanced-low, B1, etc.), but without any corroborating evidence. In the remaining 26 studies (55\%) $[1,3,4,5,6,9,13,14,18,19,20,22,23,25,26,29,30,32,36,38,40,41,42,43,44,45]$ the competency level of students can only be determined based on circumstantial evidence (e.g., graduating L2 majors, students in an AL2 graduate course, admission to a university where the L2 was the language of instruction, etc.).

Based on the information that could be gleaned from these studies, the competence level of $20 \%$ of the students described as advanced-level learners was in fact no more than Intermediate-high on the ACTFL scale (Figure 6). Only half of the students were above the Advanced-low range.

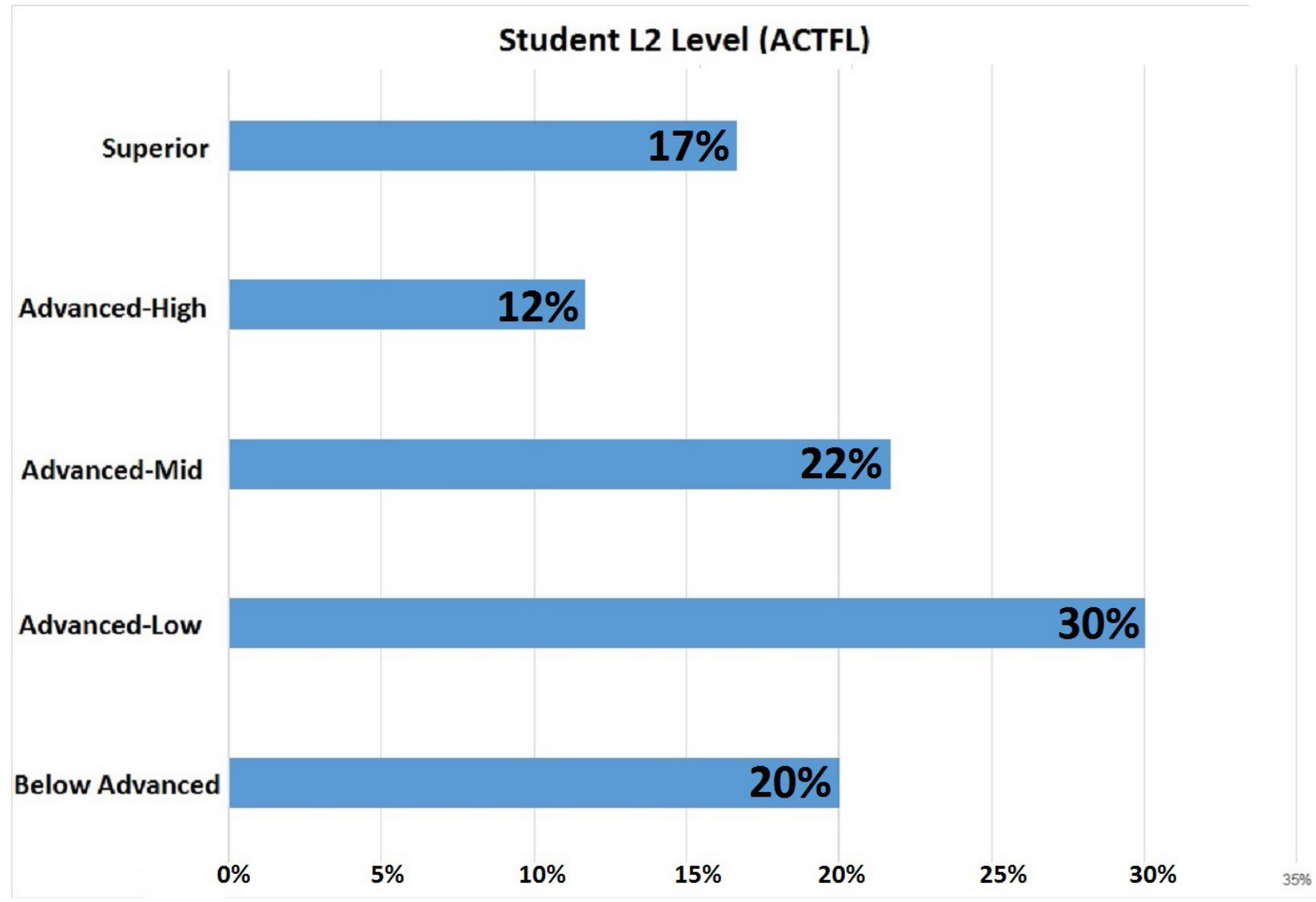

Figure 6 
This is an author-produced, peer-reviewed version of this article. The final, definitive version of this document can be found online at Calico Journal, published by the Calico Journal. Copyright restrictions may apply. doi: 10.1558/cj.31594

Research Question 3: What is the proficiency level required by assigned tasks and how is it substantiated?

Even more so than with the definition of advanced-level competence in the description of CALL AL2 studies, identification of the linguistic level of the actual language activities undertaken by students in the projects leaves much undetermined. The estimated range of language activity levels extends from Intermediate-low to Superior, of which $35 \%$ are below the Advanced level (Figure 7). In fact, of the 47 implementation studies, only one [34] explicitly identified and substantiated task level with reference to an objective external metric. Three others $[9,12,43]$ defined the task level explicitly, but without any substantiation. The task level of the remaining 43 (92\%) could only be determined through interpretation of the activities undertaken. In all but two cases $[38,40]$, this nonetheless provided a reasonable estimate of task difficulty level upon which the following analysis is based.

\title{
Task Difficulty Level
}

\section{Superior}

$13 \%$

\author{
Advanced-high
} $21 \%$

\author{
Advanced-mid
}

$13 \%$

Advanced-low $15 \%$

Intermedite-high $15 \%$

\author{
Intermediate-mid
}

$11 \%$

\section{Intermediate-low}

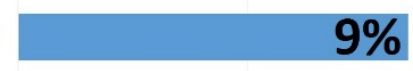

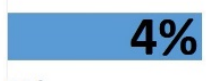

$0 \%$
$5 \%$
$10 \%$
$15 \%$
$20 \%$

Figure 7

In estimating task difficulty, at the easiest and most difficult levels (i.e., Intermediate-low and Superior) the required competence is reasonably apparent. At the lowest level, one study [21] merely engaged students in pronunciation correction, a second [45] tested listening comprehension with or without captioning in a video about animals, while two others $[4,46]$ involved checking for basic grammar or spelling errors. These were all activities that could be accomplished at the Intermediate-low level. One notch above this in relative difficulty were five projects that involved tasks that did not require more than an Intermediate-mid level of competence. One focused on prior knowledge and topic interest in a non-technical text about the origin of the universe [16]. Another involved doing repetition and practice exercises prior to free communication and the summarizing of short news events [31]. Two projects analyzed the self- initiated e-mail correspondence between students and their instructors [1,2]. The last was a study in which students were tested on their comprehension of a talk show video recording, wrote sentences using idioms that were encountered, and expressed their opinion about cultural behaviors they observed [8]. 
This is an author-produced, peer-reviewed version of this article. The final, definitive version of this document can be found online at Calico Journal, published by the Calico Journal. Copyright restrictions may apply. doi: 10.1558/cj.31594

Seven projects called upon linguistic competence usually associated with the Intermediate-high level. Four $[5,11,25,32]$ required the writing of academic essays with a focus on thematic organization and development. One involved text chat on cultural topics between native-speakers and non-native-speakers [42]. Lastly, two studies [18,34] engaged students in the reading of texts which, though non-technical, were intended for educated native speakers.

Seven tasks were deemed to be at the Advanced-low level, three of which involved collaborative writing projects. One required students to maintain a blog relating to L2 work culture, write CVs, and cover letters, as well as role-play job interviews [13]. In another, pre- service EFL teachers created a wiki summarizing the contents of their English culture course [26]. The third engaged students in peer review involving the paraphrasing and synthesizing of outside sources [22]. The four other Advanced-low tasks focused on cross-cultural comparisons requiring substantial reading and reflective discussion $[10,44]$ and depth and breadth of vocabulary knowledge [15,20].

The remaining studies all engaged participants in activities that can unequivocally be deemed to require more advanced L2 competency. The Advanced-mid level is represented in six studies, five of which engaged students in collaborative writing. The most extensive of these [24] involved a native-/non-native-speaker blog, supplemented by video chat sessions, requiring cross-cultural reflection and analysis. Two other blogs provided the platform for formal peer review, one focusing on provocative socio-cultural issues [35], the other engaged students in a wide range of writing that included reviews, reports, proposal and essays [43]. Another study exploited a wiki to support the acquisition of genre-based writing conventions [14]. The fifth collaborative writing project was based on a Google doc, which students used to integrate and synthesize information on a complex topic from multiple authentic documents [39]. The last task at the Advanced-mid level required reading professional technical texts and newspaper articles [33].

At ten, the greatest number of advanced competency tasks was at the Advanced-high level, all characterized by their highly academic disciplinary nature. Seven of these involved collaborative writing projects using various forms of CMC (i.e., discussion boards, wikis, e-mail, text chat, Google docs, etc.). Developing argument structure and rhetorical constructs was the focus of three of the studies $[3,19,29]$. Three others involved formal academic discussions $[17,27,36]$. The seventh study engaged students in both interpersonal and presentational writing tasks as well as reading, speaking and listening activities in the context of an extensive professional role playing project [30]. In addition, one study involved an individual writing task based on corpus consultation [6]. The last two tasks estimated to be at the Advanced-high level required students to read online texts dealing with economics [12] and brain research [28]. At the highest level, six of the projects, all of which involving graduate students, were based on writing assignments that obviously required Superior proficiency: writing professional academic research papers [7,23,41,47], technical reports [9] and translation commentaries [37].

\section{Research Question 4: Do CALL materials in question improve AL2 learners' linguistic proficiency?}

With regard to linguistic gains (i.e., proficiency), surprisingly, 19 of the 47 studies (40\%) do not actually target learning outcomes. Instead, they describe effects of prior knowledge on technology use [16] communication and reading strategies $[1,2,19,26,33]$, interactional patterns [25,30,40,42,44], tool evaluation [20,24,35,36], CALL design/models [37,38,46] and attitudes about technology [22]. Of the remaining 28 studies $(60 \%)$ that do target learning outcomes, a staggering $86 \%$ (24) claim that participants made significant improvements. Such claims, however, do not stand up well to close inspection. Firstly, in $3(11 \%)$ of the studies $[7,18,43]$ learning gains were determined uniquely on the basis of student self-evaluations. In another nine cases (38\%) [5,6,9,14,15,32,34,45,47], although objectively-based on pre/post-test comparisons (with or without self-evaluations), the claimed results are questionable owing to unspecified or very low participation numbers and/or the short duration of the treatment. While there are no hard and fast rules for statistical results to be generalizable, for the purposes of this analysis it was judged reasonable to remove these nine from consideration since they either did not specify participant numbers or involved less than 10 students and/or lasted less than four weeks. Thus only 43\% (12/28) [3,4,8,17,21,23,27,28,29,31,39,41] of the studies that focus on learning outcomes involved a sufficient number of participants and treatment duration to be confidently regarded as demonstrating statistically significant improvements. 
This is an author-produced, peer-reviewed version of this article. The final, definitive version of this document can be found online at Calico Journal, published by the Calico Journal. Copyright restrictions may apply. doi: 10.1558/cj.31594

Research Question 5: What is the relationship between linguistic task difficulty and the proficiency level of the participants?

The relationship between linguistic task difficulty and the proficiency level of students affects CALL AL2 studies in two critical ways. Most generally, it reflects the appropriateness of pedagogical interventions. As learning theorists have long recognized, for example in terms of i+1 (Krashen, 1981) or ZPD (Vygotsky, 1978), it is essential that students undertake tasks that are difficult enough to challenge them but not so much as to be beyond their grasp. When the 28 studies that targeted learning outcomes are regarded from this perspective, well over a third (36\%) fall outside of this range. A quarter of the studies engaged learners in tasks requiring less than their claimed proficiency level $[4,5,6,11,27,32,34]$ and $11 \%[7,14,41]$ expected too much - probing at least two ACTFL sub-levels beyond. Excluding one study [21] that lacked sufficient information to determine task difficulty, only 17 (61\%) $[3,8,9,10,12,13,15,17,18,23,28,29,31,39,43,45,47]$ remain that can be said to engage learners in a task appropriate to their perceived level of competence (Figure 8).

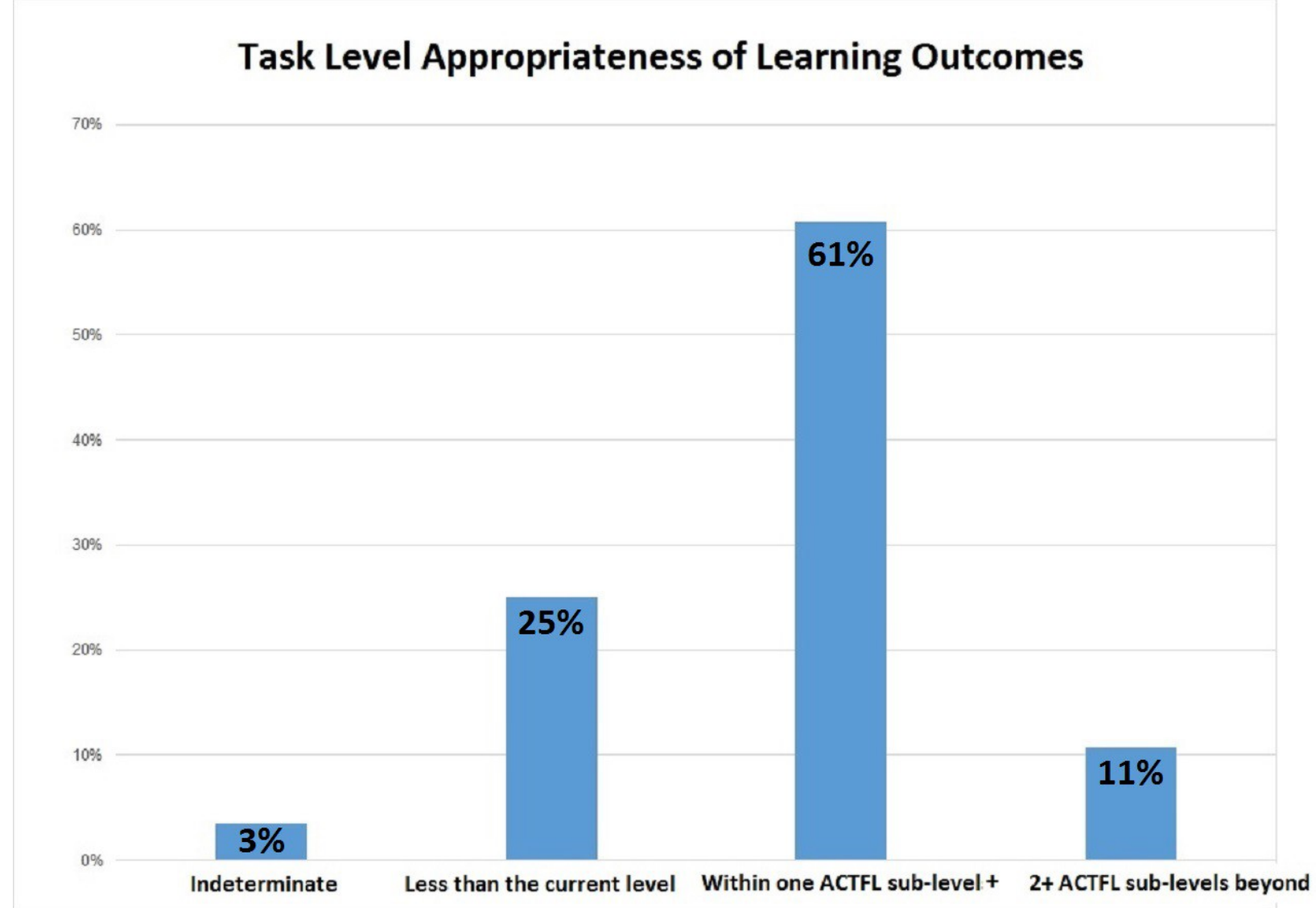

Figure 8

The second way in which linguistic task difficulty and student proficiency level affects CALL AL2 studies is in relation to the claimed learning gains discussed previously. Of the 24 studies that report successful learning outcomes, just half $[3,8,9,15,17,23,28,29,31,39,45,47]$ meet the criteria of generalizable objective measurement and are based on the completion of tasks appropriately scaffolded to the level of the participants. In sum, only about a quarter (12/47) of CALL AL2 studies report significant linguistic gains and satisfy the experimental design and pedagogical parameters to substantiate the results. 
This is an author-produced, peer-reviewed version of this article. The final, definitive version of this document can be found online at Calico Journal, published by the Calico Journal. Copyright restrictions may apply. doi: 10.1558/cj.31594

\section{Discussion}

The objective of this study was firstly to characterize what has been done in CALL at the AL2 level. The data reveal that research in this area is extremely limited and of relatively recent origin, with only one study appearing before 2000. The majority of studies (62\%) focus on English as a second or foreign language and for the four journals in question, the work is primarily being undertaken in the U.S. One is left wondering if languages like Spanish, French and German - usually the hallmark of any U.S. Higher Education Foreign Language Program - are so little represented in these studies because many learners of these languages simply don't make it to an advanced level. As with the languages targeted, so, too, their linguistic focus is extremely narrow, with $81 \%$ involving written communication. While reading and writing undoubtedly constitute essential aspects of advanced-level proficiency, spoken language fluency is no less important. Certainly aural-oral proficiency is a major component of the ACTFL Proficiency Guidelines. It is also a competency that motivates students themselves to pursue language studies beyond minimal graduation requirements (“ACTFL K-12 Foreign-Language Report 2010”, 2010, p. 1). Yet, in this metaanalysis just six studies are concerned with oral proficiency gains (four interpersonal speaking and one presentational speaking), of which but one [31] with statistically meaningful results.

Aside from quantitative and qualitative limitations, the studies examined here suffer from pervasive shortcomings in design and methodology. Despite an abundance of well-established proficiency descriptors, such as those of the CEFR (Verhelst et al., 2009) and ACTFL, identification of learner competency levels is frequently vague and at times nonexistent. From the outset, over a fifth of the studies had to be excluded from consideration for want of adequate substantiation of the claimed proficiency level of students. So, too, among the studies retained for analysis, upon close inspection $20 \%$ of the learners were in all probability below the advanced-low threshold. Lack of clarity likewise effects the description of the tasks undertaken and the language competence required to successfully complete them. Needless to say, this begs a fundamental question about what CALL researchers and developers actually know about AL2. Arguably, this is not just a CALL problem, but also one that extends as well to SLA research in general. Not surprisingly, given the demonstrated lack of understanding about what constitutes advanced-level competence, analysis of the relationship between student proficiency and the linguistic difficulty level of assigned tasks reveals a significant mismatch in well over a third of the studies, most notably with students undertaking tasks below their claimed competence level a quarter of the time.

\section{Conclusion}

Contrary to what one might expect, concern with improved linguistic competence motivated only $60 \%$ of the AL2 CALL studies. While learning gains are claimed in the vast majority of cases (86\%), in reality only half of the studies substantiate improvements on the basis of tasks completed at an appropriate difficulty level and objectively generalizable assessments. With less than 3\% of CALL publications in the study dealing with AL2, and of these only a quarter reporting reliably significant advanced-level learning gains, judging by the published literature it must be concluded that the contribution of CALL to AL2 has indeed been almost non-existent. Such a conclusion, brings to the fore the oft repeated observation that instructional technology is only as good as its underlying pedagogy and methodological design. As Blake (2013) reminds us

"Technology, per se, has no stake in any particular theoretical model or teaching methodology. The technology is theoretically and methodologically neutral. But how technology is used—its particular culture of practice - is not neutral; it responds to what the practitioners understand or believe to be true about SLA". (p.12)

As suggested above, the shortcomings of CALL in regard to AL2 are very much linked to the neglect of advancedlevel language competence within SLA research itself. Whatever the potential affordances CALL has to offer, and they are quite considerable, it is safe to say that any significant contribution it can make to our teaching of advancedlevel languages must await the consistent incorporation of much more explicit proficiency descriptors and the application of much more rigorous research design criteria. 
This is an author-produced, peer-reviewed version of this article. The final, definitive version of this document can be found online at Calico Journal, published by the Calico Journal. Copyright restrictions may apply. doi: 10.1558/cj.31594

\section{Limitations and Future Suggestions}

The most obvious limitation of this meta-analysis is its restriction to publications in just four CALL journals. Though prominent, they represent only about half of the CALL AL2 research that has appeared within the same time frame. It would certainly be of benefit to complement the current database with AL2 studies from other CALL journals. So, too, there is a considerable body of CALL AL2 research in non-CALL journals, technical as well as non-technical, that could add to our understanding of the contribution of instructional technology to the teaching of advanced-level language. Conference proceedings, MA and PhD dissertations, and the occasional book, also offer sources of CALL AL2 research that could be incorporated into a comprehensive study of CALL AL2.

A second, unavoidable, limitation of this study is the extent to which it has had to rely upon its authors' interpretation of critical research parameters, especially the linguistic competence of students and difficulty level of assigned tasks. In every case, the researchers were able to agree on how key words and descriptions from the study matched ACTFL criteria, however, not a single study used such standardized descriptors this way to design their project.

Looking to the future, much can be done to further our understanding of advanced-level language learning and how CALL can contribute to attaining AL2 proficiency. Firstly, studies need to increase the number of languages targeted and expand the range of linguistic focus to include a much larger proportion of aural-oral skills. Likewise, the number of participants and duration of treatment in these studies needs to be expanded to provide a basis for meaningful statistical analysis. However, this cannot be approached by simply continuing to do more of the same old thing. CALL researchers and developers need to take account of the larger theoretical and methodological/pedagogical contexts that underpin any effect between instructional technology and language growth. The same rigor implemented for data analysis must also be used when explaining and justifying the level of the participants in question and the expectations and benchmarks for the task being implemented. AL2 studies need to describe in detail the linguistic background of participants and substantiate their pre-treatment competence level according to some explicit evaluation metric. It does not suffice to simply refer to learners as "advanced" when well-established external criteria exist, such as the ACTFL and CEFR scales, that can better characterize where learners are within the vast advanced proficiency continuum. So too, AL2 studies must define and align task difficulty with the targeted competence level of participants. NCSSFLACTFL (2015) and ALTE-CEFR (2002) "Can Do" statements provide a framework for language tasks that could be used as tangible measures for assessment purposes to better pinpoint areas of linguistic growth. Finally, if CALL is to contribute to improved proficiency gains, serious attention needs to be paid to documenting objectively measurable learning outcomes.

\section{Notes}

${ }^{1}$ Other proficiency scales, such as the Common European Framework (CEFR) exist as well and their use as a reference point would have been equally possible. The selection of ACTFL was motivated by the authors' greater familiarity with its scales.

\section{Advanced Second Language CALL Bibliography Journal Articles}

[1]Biesenbach-Lucas, S. (2005). Communication topics and strategies in e-mail consultation: comparison between American and international university students. Language Learning and Technology, 9(2), 60-81. Retrievable from http://ltt.msu.edu/vol9num2/biesenbachlucas/

[2]Biesenbach-Lucas, S. (2007). Students writing emails to faculty: An examination of e- politeness among native and non-native speakers of English. Language Learning and Technology, 11(2), 59-81. Retrievable from http://lt.msu.edu/vol11num2/biesenbachlucas/

[3]Bradley, L., Lindström, B., \& Rystedt, H. (2010). Rationalities of collaboration for language learning in a wiki. ReCALL, 22(2), 247-265. Retrievable from http://journals.cambridge.org/action/displayAbstract?fromPage=online\&aid=7798118\&f

ulltextType=RA\&fileId=S0958344010000108\#

[4]Burston, J. (2001a). Exploiting the potential of a computer-based grammar checker in conjunction with selfmonitoring strategies with advanced level students of French. CALICO Journal, 18(3), 499-515. Retrievable from http://www.equinoxpub.com/journals/index.php/CALICO/article/view/23303

[5]Burston, J. (2001b). Computer-mediated feedback in composition correction. CALICO Journal, 19(1), 37-50. Retrievable from http://www.equinoxpub.com/journals/index.php/CALICO/article/view/23299 
This is an author-produced, peer-reviewed version of this article. The final, definitive version of this document can be found online at Calico Journal, published by the Calico Journal. Copyright restrictions may apply. doi: 10.1558/cj.31594

[6]Chambers, A., \& O’Sullivan, I. (2004). Corpus consultation and advanced learners' writing skills in French. ReCALL, 16(1), 158-172. Retrievable from http://journals.cambridge.org/action/displayAbstract?fromPage=online\&aid=229563\&ful

ltextType=RA\&fileId=S0958344004001211

[7]Chang, J-Y. (2014). The use of general and specialized corpora as reference sources for academic English writing: A case study. ReCALL, 26(2), 243-259. Retrievable from http://journals.cambridge.org/action/displayAbstract?fromPage=online\&aid=9231585\&f

ulltextType=RA\&fileId=S0958344014000056

[8]Chang, L. (2007). The effects of using CALL on advanced Chinese foreign language learners.

CALICO Journal, 24(2), 331-354. Retrievable from http://www.equinoxpub.com/journals/index.php/CALICO/article/view/23143

[9]Chang, P. (2012). Using a stance corpus to learn about effective authorial stance-taking: a textlinguistic approach. ReCALL, 24(2), 209-236. Retrievable from http://journals.cambridge.org/action/displayAbstract?fromPage=online\&aid=8553308\&f

ulltextType=RA\&fileId=S0958344012000079

[10]Chun, D. (2011). Developing intercultural communicative competence through online exchanges. CALICO Journal, 28(2), 392-419. Retrievable from http://www.equinoxpub.com/journals/index.php/CALICO/article/view/22994

[11]Craven, M.-L. (1988). Evaluating CUES: Some problems and issues in experimental CALL research. CALICO Journal, 5(3), 51-64. Retrievable from http://www.equinoxpub.com/journals/index.php/CALICO/article/view/23557

[12]De Ridder, I. (2002). Visible or invisible links: Does the highlighting of hyperlinks affect incidental vocabulary learning, text comprehension, and the reading process? Language Learning and Technology, 6(1), 123-146. Retrievable from http://lit.msu.edu/vol6num1/pdf/deridder.pdf

[13]Dippold, D. (2009). Peer feedback through blogs: Student and teacher perceptions in an advanced German class. ReCALL, 21(1), 18-36. Retrievable from http://journals.cambridge.org/action/displayAbstract?fromPage $=$ online\&aid=3786932\&f

ulltextType=RA\&fileId=S095834400900010X

[14]Elola, I., \& Oskoz, A. (2010). Collaborative writing: Fostering foreign language and writing conventions development. Language Learning and Technology, 14(3), 51-71. Retrievable from http://ltt.msu.edu/issues/october2010/elolaoskoz.pdf

[15]Ercetin, G. (2003). Exploring ESL learners' use of hypermedia reading glosses. CALICO Journal, 20(2), 261283. Retrievable from http://www.equinoxpub.com/journals/index.php/CALICO/article/view/23237

[16]Erçetin, G. (2010). Effects of topic interest and prior knowledge on text recall and annotation use in reading a hypermedia text in the L2. ReCALL, 22(2), 228-246. Retrievable from http://journals.cambridge.org/action/displayAbstract?fromPage=online\&aid=7798115\&f

ulltextType=RA\&fileId=S0958344010000091

[17]Fitze, M. (2006). Discourse and participation in ESL face-to-face and written electronic conferences. Language Learning and Technology, 10(1), 67-86. Retrievable from http://ltt.msu.edu/vol10num1/pdf/fitze.pdf

[18]Garrett-Rucks, P., Howles. L., \& Lake,W. (2015). Enhancing L2 reading comprehension with hypermedia texts: Student perceptions. CALICO Journal, 32(1), 26-51. Retrievable from http://www.equinoxpub.com/journals/index.php/CALICO/article/view/26131

[19]Hadjistassou, S. (2012). An activity theory exegesis on conflict and contradictions in networked discussions and feedback exchanges. CALICO Journal, 29(2), 367-388. Retrievable from http://www.equinoxpub.com/journals/index.php/CALICO/article/view/23734

[20]Hamel, M.-J., \& Caws, C. (2010). Usability tests in CALL development: Pilot studies in the context of the Dire autrement and Francotoile Projects. CALICO Journal, 27(3), 491-504. Retrievable from http://www.equinoxpub.com/journals/index.php/CALICO/article/view/23024

[21]Hardison, D. (2005). Contextualized computer-based L2 prosody training: evaluating the effects of discourse context and video input. CALICO Journal, 22(2), 175-190.

Retrievable from http://www.equinoxpub.com/journals/index.php/CALICO/article/view/23182

[22]Ho, M-C., \& Savignon, S. (2007). Face-to-face and computer-mediated peer review in EFL writing. CALICO Journal, 24(2), 269-290. Retrievable from http://www.equinoxpub.com/journals/index.php/CALICO/article/view/23140 
This is an author-produced, peer-reviewed version of this article. The final, definitive version of this document can be found online at Calico Journal, published by the Calico Journal. Copyright restrictions may apply. doi: 10.1558/cj.31594

[23]Hsieh, W-M., \& Liou, H-C. (2008). A case study of corpus-informed online academic writing for EFL graduate students. CALICO Journal, 26(1), 28-47. Retrievable from http://www.equinoxpub.com/journals/index.php/CALICO/article/view/22868

[24]Jauregi, K., \& Bañados, E. (2008). Virtual interaction through video-web communication: A step towards enriching and internationalizing language learning programs. ReCALL, 20(2), 183-207. Retrievable from http://journals.cambridge.org/action/displayAbstract?fromPage=online\&aid=1818920\&fulltextType=RA\&f ileId=S0958344008000529

[25]Kessler, G. (2009). Student-initiated attention to form in wiki-based collaborative writing. Language Learning and Technology, 13(1), 79-95. Retrievable from http://lit.msu.edu/vol13num1/kessler.pdf

[26]Kessler, G., \& Bikowski, D. (2010). Developing collaborative autonomous learning abilities in computer mediated language learning: attention to meaning among students in wiki space. Computer-Assisted Language Learning, 23(1), 41-58. http://www.tandfonline.com/doi/pdf/10.1080/09588220903467335

[27]Kessler, G., Bikowski, D., \& Boggs, J. (2012). Collaborative writing among second language learners in academic web based projects. Language Learning \& Technology, 16(1), 91-109. Retrievable from http://lit.msu.edu/issues/february2012/kesslerbikowskiboggs.pdf

[28]Kol, S., \& Schcolnik, M. (2000). Enhancing screen reading strategies. CALICO Journal, 18(1), 67-80. Retrievable from http://www.equinoxpub.com/journals/index.php/CALICO/article/view/23323

[29]Kol, S., \& Schcolnik, M. (2008). Asynchronous forums in EAP: Assessment issues. Language Learning \& Technology, 12(2), 49-70. Retrievable from http://ltt.msu.edu/vol12num2/kolschcolnik.pdf

[30]Leahy, C. (2004). Researching language learning processes in open CALL settings for advanced learners. Computer-Assisted Language Learning, 17(3-4), 289-313. Retrievable from http://www.tandfonline.com/doi/pdf/10.1080/0958822042000319593

[31]Lys, F. (2013). The development of advanced learner oral proficiency using iPads. Language Learning \& Technology, 17(3), 94-116. Retrievable from http://ltt.msu.edu/issues/october2013/lys.pdf

[32]Martínez Lirola, M., \& Tabuenca Cuevas, M. (2008). Integrating CALL and Genre Theory: A proposal to increase students' literacy. ReCALL, 20(1), 67-81. Retrievable from http://journals.cambridge.org/action/displayAbstract?fromPage=online\&aid=1584916\&fulltextType=RA\&f ileId=S095834400800061X

[33]Park, J., Yang, J-S., \& Chin Hsieh, Y-C. (2014). University level second language readers' online reading and comprehension strategies. Language Learning \& Technology, 18(3), 148-172. Retrievable from http://lit.msu.edu/issues/october2014/parkyanghsieh.pdf

[34]Poole, R. (2012). Concordance-based glosses for academic vocabulary acquisition. CALICO Journal, 29(4), 679-693. Retrievable from http://www.equinoxpub.com/journals/index.php/CALICO/article/view/23714

[35]Rivens Mompean, A. (2010). The development of meaningful interactions on a blog used for the learning of English as a Foreign Language. ReCALL, 22(3), 376-395. Retrievable from http://journals.cambridge.org/action/displayAbstract?fromPage=online\&aid=7884183\&fulltextType=RA\&f ileId $=$ S0958344010000200

[36]Sadler, R. (2007). Computer-mediated communication and a cautionary tale of two cities. CALICO Journal, 25(1), 11-30. Retrievable from http://www.equinoxpub.com/journals/index.php/CALICO/article/view/23120

[37]Shei, C. (2005). Integrating content learning and ESL writing in a translation commentary writing aid. Computer-Assisted Language Learning, 18(1-2), 33-48. http://www.tandfonline.com/doi/pdf/10.1080/09588220500132266

[38]Söntgens, K. (2001). Circling the globe: Fostering experiential language learning. ReCALL, 13(1), 59-66. Retrievable from http://journals.cambridge.org/action/displayAbstract?fromPage=online\&aid=82585\&fulltextType=RA\&file $\mathrm{Id}=\mathrm{S} 0958344001000611$

[39]Strobl, C. (2014). Affordances of Web 2.0 technologies for collaborative advanced writing in a foreign language. CALICO Journal, 31(1), 1-18. Retrievable from http://www.equinoxpub.com/journals/index.php/CALICO/article/view/22799

[40]Sun, Y-C., \& Chang, Y-J. (2012). Blogging to learn: becoming EFL academic writers through collaborative dialogues. Language Learning \& Technology, 16(1), 43-61. Retrievable from http://llt.msu.edu/issues/february2012/sunchang.pdf

[41]Tsai, Y-R. (2015). Applying the Technology Acceptance Model (TAM) to explore the effects of a Course Management System (CMS)-Assisted EFL writing instruction. CALICO Journal, 32(1), 153-171. Retrievable from http://www.equinoxpub.com/journals/index.php/CALICO/article/view/25961 
This is an author-produced, peer-reviewed version of this article. The final, definitive version of this document can be found online at Calico Journal, published by the Calico Journal. Copyright restrictions may apply. doi: 10.1558/cj.31594

[42]Vandergriff, I. (2013). "My major is English, belive it or not:)" - Participant orientations in nonnative/native text chat. CALICO Journal, 30(3), 393-409. Retrievable from http://www.equinoxpub.com/journals/index.php/CALICO/article/view/22813

[43]Vurdien, R. (2013). Enhancing writing skills through blogging in an advanced English as a Foreign Language class in Spain. Computer-Assisted Language Learning, 26(2), 126-143. Retrievable from http://www.tandfonline.com/doi/pdf/10.1080/09588221.2014.881386\#.VfPqrpeTQZw

[44]Ware, P. (2005). 'Missed' communication in online communication: Tensions in a German- American telecollaboration. Language Learning \& Technology, 9(2), 64-89. Retrievable from http://lit.msu.edu/vol9num2/ware/default.html

[45]Winke, P., Susan Gass, S., \& Sydorenko, T. (2010). The effects of captioning videos used for foreign language listening activities. Language Learning \& Technology, 14(1), 65-86. Retrievable from http://llt.msu.edu/vol14num1/winkegasssydorenko.pdf

[46]Xu, J., \& Bull, S. (2010) Encouraging advanced second language speakers to recognise their language difficulties: A personalised computer-based approach. Computer-Assisted Language Learning, 23(2), 111127. Retrievable from http://www.tandfonline.com/doi/pdf/10.1080/09588221003666206

[47]Yoon, H. (2008). More than a linguistic reference: The influence of corpus technology on L2 academic writing. Language Learning \& Technology, 12(2), 31-48. Retrievable from http://llt.msu.edu/vol12num2/yoon.pdf

\section{References}

ACTFL. (2010). ACTFL K-12 Foreign-Language Report 2010. Retrievable from https://www.ced.org/pdf/actfl-k12foreign-language-for-global-society.pdf

ACTFL. (2015). ACTFL Performance Descriptors for Language Learners. Retrievable from https://www.actfl.org/sites/default/files/pdfs/ACTFLPerformance-Descriptors.pdf

ACTFL. (2015). NCSSFL-ACTFL Can-Do Statements. Retrievable from http://www.actfl.org/sites/default/files/pdfs/Can-Do_Statements 2015.pdf

Adelman, C. (1995). The New College Course Map and Transcript File. Washington, DC: U.S. Department of Education. Retrievable from http://files.eric.ed.gov/fulltext/ED434647.pdf

ALTE. (2002). The ALTE can do project. Retrievable from http://www.alte.org/attachments/files/alte_cando.pdf

Blake, R. J. (2013). Brave new digital classroom: Technology and foreign language learning. Georgetown University Press.

Burston, J. (2015). Twenty years of MALL project implementation: A meta-analysis of learning outcomes. ReCALL, 27(01), 4-20. Retrievable from http://journals.cambridge.org/action/displayAbstract?fromPage=online\&aid=9455682\&f

ulltextType=RA\&fileId=S0958344014000159

Carroll, J. (1967). Foreign language proficiency levels attained by language majors near graduation from college. Foreign Language Annals, 1(2), 131-151. Retrievable from http://onlinelibrary.wiley.com/wol1/doi/10.1111/j.1944-9720.1967.tb00127.x/full

Chiu, Y. H., Kao, C. W., \& Reynolds, B. L. (2012). The relative effectiveness of digital game---based learning types in English as a foreign language setting: A meta---analysis. British Journal of Educational Technology, 43(4), E104-E107. Retrievable from http://onlinelibrary.wiley.com/wol1/doi/10.1111/j.14678535.2012.01295.x/full

European Commission. (2012). First European Survey on Language Competences - Final Report. Retrievable from http://ec.europa.eu/languages/library/studies/executive-summary-eslc_en.pdf

Felix, U. (2005). What do meta-analyses tell us about CALL effectiveness? ReCALL, 17(2), 269-288. Retrievable from

http://journals.cambridge.org/action/displayAbstract?fromPage=online\&aid=355490\&fulltextType=RA\&fi leId $=$ S0958344005000923

Felix, U. (2008). The unreasonable effectiveness of CALL: What have we learned in two decades of research. ReCALL, 20(2), 141-161. Retrievable from http://journals.cambridge.org/action/displayAbstract?fromPage=online\&aid=1818904\&fulltextType=RA\&f ileId $=$ S0958344008000323

Glisan, E., Swender, E., \& Surface, E. (2013). Oral proficiency standards and foreign language teacher candidates: Current findings and future research directions. Foreign Language Annals, 46(2), 264-289. Retrievable from http://onlinelibrary.wiley.com/doi/10.1111/flan.12030/epdf 
This is an author-produced, peer-reviewed version of this article. The final, definitive version of this document can be found online at Calico Journal, published by the Calico Journal. Copyright restrictions may apply. doi: 10.1558/cj.31594

Goldberg, D., Looney, D., \& Lusin, N., (2015). Enrollments in Languages Other than English in United States Institutions of Higher Education, Fall 2013. Modern Language Association of America: New York. Retrievable from https://apps.mla.org/pdf/2013 enrollment_survey.pdf

Krashen, S. (1981). Second Language Acquisition and Second Language Learning. Oxford, UK: Pergamon.

Lin, H. (2014). Establishing an empirical link between computer-mediated communication (CMC) and SLA: A meta-analysis of the research. Language Learning \& Technology, 18(3), 120-147. Retrievable from http://llt.msu.edu/issues/october2014/lin.pdf

Lusin, N. (2012).The MLA survey of postsecondary entrance and degree requirements for languages other than English, 2009-10, 1-9. Modern Language Association of America. https://www.mla.org/content/download/3316/81618/requirements survey_200910.pdf

Nguyen, L. V. (2008). Computer mediated communication and foreign language education: Pedagogical features. International Journal of Instructional Technology and Distance Learning, 5(12), 23-44. Retrievable from http://itdl.org/Journal/Dec_08/article02.htm

Plonsky, L., \& Ziegler, N. (2016). The CALL-SLA interface: Insights from a second-order synthesis. Language Learning \& Technology, 20(2), 17-37. Retrievable from http://ltt.msu.edu/issues/june2016/plonskyziegler.pdf

Taylor, A. (2013). CALL versus paper: In which context are L1 glosses more effective? CALICO Journal, 30(1), 63-81. Retrievable from https://journals.equinoxpub.com/index.php/CALICO/article/view/22911/18932

Verhelst, N., Van Avermaet, P., Takala, S., Figueras, N., \& North, B. (2009). Common European Framework of Reference for Languages: learning, teaching, assessment. Cambridge University Press. Retrievable from http://www.coe.int/t/dg4/linguistic/Source/Framework_EN.pdf

Vygotsky, L. (1978). Mind in Society: The Development of Higher Psychological Processes. Cambridge, MA: Harvard University Press.

Yun, J. (2011). The effects of hypertext glosses on L2 vocabulary acquisition: A meta-analysis. Computer Assisted Language Learning, 24(1), 39-58. Retrievable from http://www.tandfonline.com/doi/full/10.1080/09588221.2010.523285

Ziegler, N. (2015). Synchronous computer-mediated communication and interaction. Studies in Second Language Acquisition, 1-34. Retrievable from http://journals.cambridge.org/action/displayAbstract?aid=10000601 